\title{
RESPONSE OF SOME NARBON VETCH VARIETIES TO DIFFERENT DEFOLIATION INTENSITIES CONCERNING FORAGE, SEED YIELD AND GROWTH TRAITS UNDER RAINFED CONDITIONS OF THE SULAIMANI GOVERNORATE, IRAQ
}

\author{
Muhammed, S. R. - Ahmed, D. A. - Sleman, S. M. ${ }^{*}$ - Hussaen, R. A. \\ Department of Biotechnology and Crop Science, College of Agricultural Engineering Sciences, \\ University of Sulaimani, Sulaymaniyah, Iraq \\ (e-mails: sanarya.muhammed@univsul.edu.iq,dastan.ahmed@univsul.edu.iq, \\ roonak.hussaen@univsul.edu.iq) \\ *Corresponding author \\ e-mail:shokhan.sleman@univsul.edu.iq
}

(Received $14^{\text {th }}$ May 2019; accepted 20 ${ }^{\text {th }}$ Aug 2019)

\begin{abstract}
To study the response of some narbon vetch varieties to different defoliation intensities on forage, seed yield and their components under rain fed condition. A field experiment was conducted at College of Agricultural Sciences-University of Sulaimani in Iraq country during the winter season of 2017-2018, using split plot design. Three varieties of narbon vetch (ICARDA 2561, ICARDA 2380 and ICARDA 2706) were implemented in the main plots and arranged according to Randomized Complete Block Design and replicated three times, and four defoliation intensities (different height of forage cutting from ground level) Control (not defoliated), Low $=8 \mathrm{~cm}$, Moderate $=6 \mathrm{~cm}$ and Severe $=4 \mathrm{~cm}$ from ground level) were allotted in subplots. Means comparisons were carried out using the least significant difference test (LSD) at 5\% and 1\% significant levels. The results of this study indicated that the interaction between ICARDA 2561 and moderate defoliation intensity gave the highest values of fresh forage yield and fresh stem percent, and the interaction between ICARDA 2380 and severe defoliation intensity gave maximum fresh leaf percent, Regarding leaves/stem ratio, maximum ratio showed by interaction between ICARDA 2561 and low defoliation intensity. The interaction between ICARDA 2380 and moderate defoliation intensity awarded the highest values of most traits such as plant height, no. of branches/plant, no. of leaves/plant, leaves weight/plant, leaves dry weight/plant and stem dry weight $/$ plant, Maximum values of these traits biological yield, pods number $/ \mathrm{m}^{2}$, pod yield, seed number/pod and seed yield reached attained by the interaction between ICARDA 2706 and control treatment, but the interaction between ICARDA 2561 and control treatment gave the highest values of pod length and seeds weight/pod but concerning 100 seeds weight, the highest weight obtained by interaction between ICARDA 2380 and control treatment.
\end{abstract}

Keywords: Vicia narbonensis, lines, cutting height, growth, yield, yield components, dry matter percent

\section{Introduction}

The genus Vicia is made up of approximately 190 species worldwide. The genus is primarily found in the Mediterranean and Irano- Turanian regions. However, the genus Vicia is widely distributed in the temperate zone of the northern hemisphere and in extra-tropical South America (Tahereh et al., 2012). Narbon vetch (Vicia narbonensis L.), which is resistant to cold and drought, is an annual legume species (Aç1kgöz, 2001; Firıncioğlu et al., 2012). Vetch can be grazed by animals as fresh forage (Haddad, 2006) or can be cut and preserved as hay and silage (Abdullah et al., 2010). Vetches hay can be used as a protein supplement, and their grains serve as energy and protein sources in the rations of ruminants and non-ruminants (Sadeghi et al., 2009). 
The potential of narbon vetch for grain production as livestock feed is greater than other vetch species, and the grain contains tannin and trypsin inhibitors that is directly affecting its efficiency of feed (Berger et al., 2002; Larbi et al., 2010), in general narbon vetch is cultivated for grain production (Buyukburc and Iptas, 2001). The species also has great importance in the system of crop rotation, either as pure stands or in a mixture with cereals for green forage or hay production to provide high-quality of livestock feed (Altınok, 2002; Altınok and Hakyemez, 2002; Iptaş and Karadağ, 2009; Nizam et al., 2011). Furthermore, narbon vetch is used as a valuable green manure plant, because it produce a high amount of green biomass, and its ability to fix large amounts of nitrogen to the soil as a legume (Albayrak et al., 2004a, b; Avcioğlu et al., 2009; Firıncioğlu et al., 2012).

Narbon vetch is a fast-growing crop, with vigorous regrowth ability, and does better under warm temperatures and drier conditions (annual rainfall amount below $350 \mathrm{~mm}$ ) than faba bean. It is tolerant to cold. When aerial parts damaged by frost may be die, but new shoots regrow when conditions will better in the spring. It can grow in many types of soils from sandy soils to loams provided they are well-drained. The input requirement of narbon vetch has low (fertilizer and pesticides) but does particularly well on alkaline soils and responds positively to P fertilizer (Mebarkia et al., 2013; SanchezVioque et al., 2011). Like many other Vicia species, the culture of Vicia narbonensis L. has long been neglected due to the presence of anti-nutritional factors that also cause an undesirable odorand taste in grain and foliage. Once cooked, the anti-nutritional factors removed, and Narbon beans can be eaten and are described as being of high quality (Bryant et al., 2011).

Forage growers cut forages frequently at a height of 3-inches or more. However, recent reports indicate that there may be an advantage to cutting crop closer, leaving an inch or less of stubble height, which was found that annual alfalfa yields were 1.6 tons per acre higher when cutting at 1-inches compared to 5-inches heights (@griculture Online, 1999).

A study from West Virginia reports that alfalfa cut at 1 or 2 inches yielded as much as 38\% more than alfalfa cut at 4 inches (Belesky and Fedders, 1997). A reduction of a $1 / 2$ ton of dry matter per inch as cutting height increased from 2 to 6 inches above the ground when combined across three harvests for the year (Wiersma, 2000).

However, there is little information available on the forage yield of narbon vetches grown under climatic conditions of Sulaimani. Therefore, the current study aimed to determine forage and seed yields for three varieties of narbon vetch (Vicia narbonensis L.) at different defoliation intensities, and which variety has ability to adapt with our condition and regrowth after defoliation to produce high yield crop.

\section{Materials and methods}

A field experiment was conducted at College of Agricultural Engineering SciencesUniversity of Sulaimani located (Latitude: $3533^{\prime}$ N, Longitude $45^{\circ} 27^{\prime}$ E, at altitude of approximately $830 \mathrm{~m}$ ) during the winter season of 2017-2018, to study the effect of different varieties and defoliation intensities on growth, forage, seed yield and its components of narbon vetch (Vicia narbonensis L.) under rainfed condition conducting in split-plot design. Three varieties of narbon vetch (ICARDA 2561, ICARDA 2380 and ICARDA 2706) were implemented in the main plots and arranged according to the randomized complete block design (CRBD) and replicated three times, and four 
defoliation intensities (different height of forage cutting from ground level) (Control (not defoliated), Low $=8 \mathrm{~cm}$, Moderate $=6 \mathrm{~cm}$ and Severe $=4 \mathrm{~cm}$ from ground level) were allotted in subplots for seed traits, but for forage traits treatments were allotted without control (Low $=8 \mathrm{~cm}$, Moderate $=6 \mathrm{~cm}$ and Severe $=4 \mathrm{~cm}$ from ground level). Each subplot consists of 3 rows, $2 \mathrm{~m}$ long with $0.30 \mathrm{~m}$ apart between rows.

Sowing was conducted during $12^{\text {th }}$ December 2017 according to the recommended seed rates $120 \mathrm{~kg} / \mathrm{ha}$ for three varieties and all plots were fertilized with $120 \mathrm{~kg} \mathrm{P} \mathrm{P}_{5} / \mathrm{ha}$ as triple superphosphate, which was broadcasting before sowing, and the germination percentage for each used varieties was higher than \% 95. All required agricultural practices were used as needed. Forage cutting conducted for all subplots on $4^{\text {th }}$ January 2018 to determine forage yield traits:

\section{Forage yield traits}

- Fresh Forage Yield (ton/ha)

- Dry Forage Yield (ton/ha)

- Fresh Leaf\%

- Dry Leaf\%

- Fresh Stem\%

- Dry Stem\%

- Dry Matter\%

- Leaves/Stem Ratio

In addition, on the same day of cutting we were taken a sample randomly ( 5 plants of each subplot) to estimate forage yield component traits were:

\section{Growth traits}

- Plant height (cm)

- No. of Branches/plant

- No. of leaves/plant

- Leaves weight/plant (g)

- Dry leaves weight/plant (g)

- Stem weight/plant (g)

- Dry Stem weight/plant (g)

- Root weight (g)

- Dry Root weight (g)

When the plants matured physiologically, harvesting was carried out on $4^{\text {th }}$ June 2018 to record seed yield traits from each plot, but the averages of 10 pods were taken from each plot to estimate yield component traits as follows:

\section{Seed yield and its components}

- Seed Yield (ton/ha),

- Biological Yield (ton/ha),

- Pods Number $/ \mathrm{m}^{2}$

- Pod yield (ton/ha)

- Average Pod Length $(\mathrm{cm})$ 
- Average Seeds Number/Pod

- Average Seeds Weight/Pod (g)

- 100 Seeds Weight $(\mathrm{g})$

The data were statistically analyzed according to the methods of analysis of variance as a general test and combined analysis conducted (AL Mohamad and AL Younis, 2000). Comparison among the means was carried out using the least significant test (L.S.D) at a significant level of 5\% and 1\% (AL Mohamad and AL Younis, 2000).

\section{Results and discussion}

Data in Table 1 and Appendix 1 indicated that the effect of varieties on forage yield traits was not significant for most characters but on the other traits such as (fresh forage yield, dry forage yield and fresh leaf percent) were found to be significant, ICARDA 2561 gave maximum value of fresh forage yield (13.356 ton/ha), while ICARDA 2380 recorded minimum value of this trait which was $(11.706$ ton/ha). But the highest dry forage yield and fresh leaf percent were (1.492 ton/ha and 63.467\%) respectively exhibited by V3, in which the lowest values of both traits were $(1.302$ ton/ha and $60.763 \%$ ) recorded by ICARDA 2380 and ICARDA 2561 regularly. These differences among varieties may be due to genetic variance and capability of each variety for best production. These results were in agreement with the results of Muhammed (2017).

Table 1. Effect of varieties on forage yield traits of narbon vetch

\begin{tabular}{c|c|c|c|c|c|c|c|c}
\hline Varieties & $\begin{array}{c}\text { Fresh forage } \\
\text { yield (ton/ha) }\end{array}$ & $\begin{array}{c}\text { Dry forage } \\
\text { yield (ton/ha) }\end{array}$ & $\begin{array}{c}\text { Fresh } \\
\text { leaf \% }\end{array}$ & $\begin{array}{c}\text { Fresh stem } \\
\text { \% }\end{array}$ & $\begin{array}{c}\text { Dry leaf } \\
\text { \% }\end{array}$ & $\begin{array}{c}\text { Dry stem } \\
\%\end{array}$ & $\begin{array}{c}\text { Dry matter } \\
\%\end{array}$ & $\begin{array}{c}\text { Leaves/stem } \\
\text { ratio }\end{array}$ \\
\hline ICARDA 2561 & 13.356 & 1.393 & 60.763 & 39.237 & 7.450 & 3.032 & 10.482 & 1.337 \\
ICARDA 2380 & 11.706 & 1.302 & 63.358 & 36.642 & 7.957 & 3.167 & 11.123 \\
ICARDA 2706 & 13.130 & 1.492 & 63.467 & 36.867 & 8.242 & 3.100 & 11.342 & 1.082 \\
LSD (P < 0.05) & 0.923 & 0.079 & 2.171 & N.S & N.S & N.S & N.S & N.S \\
\hline
\end{tabular}

N.S: not significant

The results of Table 2 and Appendix 1 confirmed that the effect of defoliation intensities on all forage yield traits was significant except these characters' dry forage yield, dry stem percent, and dry matter percent were found to be not significant. Moderate defoliation intensity $(6 \mathrm{~cm})$ gave maximum values of fresh forage yield, fresh stem percent and leaves/stem ratio was (13.907 ton/ha, 39.971\% and 1.356) respectively, while minimum values of fresh forage yield and fresh stem percent were (12.054 ton/ha and 35.404\%) registered by low defoliation intensity $(8 \mathrm{~cm})$, but regarding leaves/stem ratio, minimum value was 1.062 obtained by severe defoliation intensity $(4 \mathrm{~cm})$.

Concerning both traits (fresh leaf and dry leaf percent), low defoliation intensity $(8 \mathrm{~cm})$ gave the best percent $(64.929$ and $8.283 \%)$ respectively, while the lowest percentage of these both traits were $(60.029$ and $7.606 \%)$ recorded by moderate defoliation intensity $(6 \mathrm{~cm})$.

In theory, leaving tall stubble and leaves at the base of the plant provides more photosynthetic area and energy for new stem growth following harvest. Prevision results showed that cutting to the soil surface increased forage yield at the first cut by 
increasing the weight of individual shoots harvested. This is simply because defoliation closer to the soil surface removed greater part of individual shoots of plants that had been uniformly managed prior to the first harvest. Plants at the first cut in the secondyear growing season had stems arising mainly from the crown. This character- is tic of the plant canopy increased individual shoot weight steeply with decreasing cutting height reported by Shen et al. (2013), this result was in agreement with our results.

Table 2. Effect of defoliation intensities on forage yield traits of narbon vetch

\begin{tabular}{c|c|c|c|c|c|c|c|c}
\hline $\begin{array}{c}\text { Defoliation } \\
\text { intensities }\end{array}$ & $\begin{array}{c}\text { Fresh forage } \\
\text { yield (ton/ha) }\end{array}$ & $\begin{array}{c}\text { Dry forage } \\
\text { yield (ton/ha) }\end{array}$ & $\begin{array}{c}\text { Fresh } \\
\text { leaf \% }\end{array}$ & $\begin{array}{c}\text { Fresh } \\
\text { stem \% }\end{array}$ & $\begin{array}{c}\text { Dry leaf } \\
\text { \% }\end{array}$ & $\begin{array}{c}\text { Dry stem } \\
\text { \% }\end{array}$ & $\begin{array}{c}\text { Dry matter } \\
\text { \% }\end{array}$ & $\begin{array}{c}\text { Leaves/stem } \\
\text { ratio }\end{array}$ \\
\hline Low $(8 \mathrm{~cm})$ & 12.054 & 1.371 & 64.929 & 35.404 & 8.283 & 3.086 & 11.369 & 1.268 \\
Moderate $(6 \mathrm{~cm})$ & 13.907 & 1.483 & 60.029 & 39.971 & 7.606 & 3.081 & 10.687 & 1.356 \\
Severe $(4 \mathrm{~cm})$ & 12.231 & 1.334 & 62.630 & 37.370 & 7.760 & 3.132 & 10.892 & 1.062 \\
LSD $(\mathrm{P} \leq 0.05)$ & 0.656 & N.S & 1.103 & 1.216 & 0.401 & N.S & N.S & 0.166 \\
\hline
\end{tabular}

N.S: not significant

Data represented in Table 3 and Appendix 1 showed that the effect of interactions between varieties and defoliation intensities on forage yield traits was significant on some traits such as fresh forage yield, fresh leaf percent, fresh stem percent, and leaves/stem ratio, but on the others was not significant. The interaction between ICARDA 2561 and moderate defoliation intensity $(6 \mathrm{~cm})$ gave the highest values of fresh forage yield and fresh stem percent were 15.587 ton/ha and $42.53 \%$ respectively, while the lowest yield of fresh forage was 11.291 ton/ha exhibited by interaction between ICARDA 2380 and low defoliation intensity $(8 \mathrm{~cm})$, and the lowest percent of fresh stem was $33.49 \%$ obtained by interaction between ICARDA 2380 and severe defoliation intensity $(4 \mathrm{~cm})$, also this interaction gave maximum fresh leaf percent $66.51 \%$, in which minimum percent of fresh leaf was $57.47 \%$ recorded by ICARDA 2380 when treated with moderate defoliation intensity $(6 \mathrm{~cm})$. Regarding leaves/stem ratio, a maximum ratio was 1.432 showed by the interaction between ICARDA 2561 and low defoliation intensity $(8 \mathrm{~cm})$, in which the interaction between ICARDA 2380 and severe defoliation intensity $(4 \mathrm{~cm})$ recorded minimum leaves/stem ratio 0.532 .

Table 4 and Appendix 1 illustrated Effect of varieties on growth traits of narbon vetch, which was found that the effect was significant on plant height, leaves weight/plant, stem weight/plant and root dry weight, but on the other traits was not significant. The highest values of plant height, leaves weight/plant and stem weight/plant were $(44.089 \mathrm{~cm}$, $20.413 \mathrm{~g}$, and $20.013 \mathrm{~g}$ ) exhibited by ICARDA 2380, respectively, but maximum value of root dry weight was $0.922 \mathrm{~g}$ showed by variety 3, while the lowest values of these traits plant height, leaves weight/plant, stem weight/plant and root dry weight were $(34.386 \mathrm{~cm}$, $16.723 \mathrm{~g}, 12.490 \mathrm{~g}$ and 0.634) $\mathrm{g}$ recorded by (ICARDA 2706, ICARDA 2561, ICARDA 2561, and ICARDA 2380) respectively.

The differences between varieties in some growth traits may be positively and strongly related to the differences in genetic map and these adaptations to the climate. These results were in agreement with the results reported by (Muhammed, 2017).

Data in Table 5 and Appendix 1 confirmed that most growth traits of narbon vetch such as (no. of branches/plant, no. of leaves/plant, leaves weight/plant, leaves dry weight/plant and stem weight/plant) significantly affected by different defoliation intensities, while the other traits (plant height, stem dry weight/plant, root weight and root dry weight) not affected by this factor. Moderate defoliation intensity $(6 \mathrm{~cm})$ gave maximum values of 
(no. of branches/plant, no. of leaves/plant, leaves weight/plant and leaves dry weight/plant) were $(2.919,26.027,21.941 \mathrm{~g}$ and $3.070 \mathrm{~g})$ respectively, on the other hand, maximum stem weight/plant $(17.721 \mathrm{~g})$ presented by severe defoliation intensity $(4 \mathrm{~cm})$, in which minimum values of these traits (no. of branches/plant, no. of leaves/plant and leaves dry weight/plant) were $(2.294,20.257$ and $2.259 \mathrm{~g}$ ) appeared by severe defoliation intensity $(4 \mathrm{~cm})$, but concerning both traits (leaves weight/plant and stem weight/plant), the lowest values showed by low defoliation intensity $(8 \mathrm{~cm})$ which was $(16.194$ and 13.298) g respectively. Previous works confirmed that alfalfa growth in the spring is primarily from crown buds and depends on temperature and available root energy reserves. Shoot growth after the first harvest originates from both crown and auxiliary buds. When the crop is cut very short (1-inch or less) most of the axillary buds are removed and new shoots must come from the crown buds (Wiersma, 2000).

Table 3. Effect of interactions between varieties and defoliation intensities on growth traits of narbon vetch

\begin{tabular}{c|c|c|c|c|c|c|c|c|c}
\hline Varieties & $\begin{array}{c}\text { Defoliation } \\
\text { intensities }\end{array}$ & $\begin{array}{c}\text { Fresh forage } \\
\text { yield (ton/ha) }\end{array}$ & $\begin{array}{c}\text { Dry forage } \\
\text { yield (ton/ha) }\end{array}$ & $\begin{array}{c}\text { Fresh } \\
\text { leaf \% }\end{array}$ & $\begin{array}{c}\text { Fresh } \\
\text { stem \% }\end{array}$ & $\begin{array}{c}\text { Dry leaf } \\
\text { \% }\end{array}$ & $\begin{array}{c}\text { Dry } \\
\text { stem \% }\end{array}$ & $\begin{array}{c}\text { Dry } \\
\text { matter \% }\end{array}$ & $\begin{array}{c}\text { Leaves/ } \\
\text { stem ratio }\end{array}$ \\
\hline \multirow{2}{*}{ ICARDA } & Low $(8 \mathrm{~cm})$ & 11.918 & 1.323 & 65.97 & 34.03 & 8.213 & 2.887 & 11.100 & 1.432 \\
2561 & Moderate $(6 \mathrm{~cm})$ & 15.587 & 1.537 & 57.47 & 42.53 & 7.010 & 2.843 & 9.853 & 1.316 \\
& Severe $(4 \mathrm{~cm})$ & 12.564 & 1.320 & 58.85 & 41.15 & 7.127 & 3.367 & 10.493 & 1.263 \\
\hline \multirow{2}{*}{ ICARD A } & Low $(8 \mathrm{~cm})$ & 11.291 & 1.310 & 64.17 & 35.83 & 8.163 & 3.433 & 11.597 & 1.307 \\
2380 & Moderate $(6 \mathrm{~cm})$ & 11.875 & 1.262 & 59.39 & 40.61 & 7.490 & 3.150 & 10.640 & 1.408 \\
& Severe $(4 \mathrm{~cm})$ & 11.950 & 1.334 & 66.51 & 33.49 & 8.217 & 2.917 & 11.133 & 0.532 \\
\hline
\end{tabular}

N.S: not significant

Table 4. Effect of varieties on growth traits of narbon vetch

\begin{tabular}{|c|c|c|c|c|c|c|c|c|c|}
\hline Varieties & $\begin{array}{c}\text { Plant } \\
\text { height } \\
(\mathbf{c m})\end{array}$ & $\begin{array}{c}\text { No. of } \\
\text { brunches/ } \\
\text { plant }\end{array}$ & $\begin{array}{c}\text { No. of } \\
\text { leaves/plant }\end{array}$ & $\begin{array}{c}\text { Leaves } \\
\text { weight/plant } \\
\text { (g) }\end{array}$ & $\begin{array}{c}\text { Leaves dry } \\
\text { weight/plant } \\
\text { (g) }\end{array}$ & $\begin{array}{c}\begin{array}{c}\text { Stem } \\
\text { weight/plant } \\
\text { (g) }\end{array} \\
\end{array}$ & $\begin{array}{c}\text { Stem dry } \\
\text { weight/plant } \\
\text { (g) }\end{array}$ & $\begin{array}{c}\text { Root } \\
\text { weight } \\
\text { (g) }\end{array}$ & $\begin{array}{c}\text { Root dry } \\
\text { weight } \\
\text { (g) }\end{array}$ \\
\hline ICARDA 2561 & 37.123 & 2.550 & 22.101 & 16.723 & 2.243 & 12.490 & 1.456 & 2.449 & 0.729 \\
\hline ICARD A 2380 & 44.089 & 2.627 & 23.804 & 20.413 & 2.949 & 20.013 & 1.746 & 2.171 & 0.634 \\
\hline ICARDA 2706 & 34.386 & 2.626 & 22.923 & 17.541 & 2.582 & 14.572 & 1.583 & 2.528 & 0.922 \\
\hline $\operatorname{LSD}(\mathrm{P} \leq 0.05)$ & 1.692 & N.S & N.S & 2.465 & N.S & 3.427 & N.S & N.S & 0.116 \\
\hline
\end{tabular}

N.S: not significant

Table 5. Effect of defoliation intensities on growth traits of narbon vetch

\begin{tabular}{c|c|c|c|c|c|c|c|c|c}
\hline $\begin{array}{c}\text { Defoliation } \\
\text { intensities }\end{array}$ & $\begin{array}{c}\text { Plant } \\
\text { height }(\mathbf{c m})\end{array}$ & $\begin{array}{c}\text { No. of } \\
\text { brunches/ } \\
\text { plant }\end{array}$ & $\begin{array}{c}\text { No. of } \\
\text { leaves/ } \\
\text { plant }\end{array}$ & $\begin{array}{c}\text { Leaves } \\
\text { weight// } \\
\text { plant }(\mathbf{g})\end{array}$ & $\begin{array}{c}\text { Leaves dry } \\
\text { weight/ } \\
\text { plant }(\mathbf{g})\end{array}$ & $\begin{array}{c}\text { Stem } \\
\text { weight/ } \\
\text { plant }(\mathbf{g})\end{array}$ & $\begin{array}{c}\text { Stem dry } \\
\text { weight/plant } \\
(\mathbf{g})\end{array}$ & $\begin{array}{c}\text { Root } \\
\text { weight (g) }\end{array}$ & $\begin{array}{c}\text { Root dry } \\
\text { weight (g) }\end{array}$ \\
\hline Low $(8 \mathrm{~cm})$ & 39.631 & 2.589 & 22.546 & 16.194 & 2.446 & 13.298 & 1.482 & 2.278 & 0.773 \\
Moderate $(6 \mathrm{~cm})$ & 38.311 & 2.919 & 26.027 & 21.941 & 3.070 & 16.057 & 1.880 & 2.410 & 0.740 \\
Severe $(4 \mathrm{~cm})$ & 37.656 & 2.294 & 20.257 & 16.542 & 2.259 & 17.721 & 1.422 & 2.460 & 0.772 \\
LSD $(\mathrm{P} \leq 0.05)$ & N.S & 0.317 & 1.726 & 0.727 & 0.312 & 2.010 & N.S & N.S & N.S \\
\hline
\end{tabular}

N.S: not significant 
The results were obtained from Table 6 and Appendix 2 indicated that the effect of interactions between varieties and defoliation intensities on all growth traits was significant with the exception of the character root weight which was found to be not significant. The interaction between ICARDA 2380 and moderate defoliation intensity $(6 \mathrm{~cm})$ awarded the highest values of (plant height, no. of branches/plant, no. of leaves/plant, leaves weight/plant, leaves dry weight/plant and stem dry weight/plant) were $(41.59,3.553,34.420,33.537 \mathrm{~g}, 4.923 \mathrm{~g}$, and $2.830 \mathrm{~g})$ respectively, but the highest amount of stem weight/plant was $25.163 \mathrm{~g}$ offered by ICARDA 2380 when interacted with severe defoliation intensity $(4 \mathrm{~cm})$, and maximum root dry weight was $(1.073 \mathrm{~g})$ obtained by interaction between ICARDA 2706 and severe defoliation intensity $(4 \mathrm{~cm})$. while the lowest height of plant was $30.37 \mathrm{~cm}$ exhibited by interaction between ICARDA 2706 and low defoliation intensity $(8 \mathrm{~cm}$ ), but the minimum values of (no. of branches/plant, leaves dry weight/plant and stem weight/plant) were $(2.107,1.953 \mathrm{~g}$ and $11.067 \mathrm{~g}$ ) showed by ICARDA 2380 when interacted with low defoliation intensity $(8 \mathrm{~cm})$ respectively. Regarding these traits (no. of leaves/plant, leaves weight/plant, stem dry weight/plant and root dry weight), the interaction between ICARDA 2380 and severe defoliation intensity $(4 \mathrm{~cm})$ gave minimum values were $17.997,13.270 \mathrm{~g}$, $1.087 \mathrm{~g}$ and $0.570 \mathrm{~g}$, respectively.

Table 6. Effect of interactions between varieties and defoliation intensities on growth traits of narbon vetch

\begin{tabular}{|c|c|c|c|c|c|c|c|c|c|c|}
\hline Varieties & $\begin{array}{l}\text { Defoliation } \\
\text { intensities }\end{array}$ & $\begin{array}{c}\text { Plant } \\
\text { height } \\
\text { (cm) }\end{array}$ & $\begin{array}{c}\text { No. of } \\
\text { brunches/ } \\
\text { plant }\end{array}$ & $\begin{array}{c}\text { No. of } \\
\text { leaves/ } \\
\text { plant }\end{array}$ & $\begin{array}{c}\text { Leaves } \\
\text { weight/ } \\
\text { plant (g) }\end{array}$ & $\begin{array}{c}\text { Leaves dry } \\
\text { weight/ } \\
\text { plant (g) }\end{array}$ & $\begin{array}{c}\text { Stem } \\
\text { weight/ } \\
\text { plant (g) }\end{array}$ & $\begin{array}{l}\text { Stem dry } \\
\text { weight/ } \\
\text { plant (g) }\end{array}$ & $\begin{array}{c}\text { Root } \\
\text { weight } \\
(\mathrm{g}) \\
\end{array}$ & $\begin{array}{c}\text { Root dry } \\
\text { weight } \\
\text { (g) }\end{array}$ \\
\hline \multirow{3}{*}{$\stackrel{\sim}{\widetilde{D}}$} & Low $(8 \mathrm{~cm})$ & 38.21 & 3.110 & 25.533 & 18.610 & 2.590 & 13.000 & 1.597 & 2.497 & 0.780 \\
\hline & Moderate $(6 \mathrm{~cm})$ & 38.89 & 2.430 & 21.773 & 15.957 & 2.083 & 12.123 & 1.430 & 2.510 & 0.733 \\
\hline & Severe $(4 \mathrm{~cm})$ & 34.27 & 2.110 & 18.997 & 15.603 & 2.057 & 12.347 & 1.340 & 2.340 & 0.673 \\
\hline \multirow{3}{*}{ 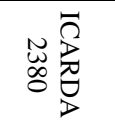 } & Low $(8 \mathrm{~cm})$ & 50.32 & 2.107 & 18.997 & 14.433 & 1.953 & 11.067 & 1.320 & 2.510 & 0.750 \\
\hline & Moderate $(6 \mathrm{~cm})$ & 41.59 & 3.553 & 34.420 & 33.537 & 4.923 & 23.810 & 2.830 & 2.107 & 0.583 \\
\hline & Severe $(4 \mathrm{~cm})$ & 40.36 & 2.220 & 17.997 & 13.270 & 1.970 & 25.163 & 1.087 & 1.897 & 0.570 \\
\hline \multirow{3}{*}{ 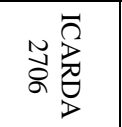 } & Low $(8 \mathrm{~cm})$ & 30.37 & 2.550 & 23.107 & 15.540 & 2.793 & 15.827 & 1.530 & 1.827 & 0.790 \\
\hline & Moderate $(6 \mathrm{~cm})$ & 34.46 & 2.773 & 21.887 & 16.330 & 2.203 & 12.237 & 1.380 & 2.613 & 0.903 \\
\hline & Severe $(4 \mathrm{~cm})$ & 38.33 & 2.553 & 23.777 & 20.753 & 2.750 & 15.653 & 1.840 & 3.143 & 1.073 \\
\hline \multicolumn{2}{|c|}{$\operatorname{LSD}(\mathrm{P}<0.05)$} & 2.318 & 0.550 & 2.989 & 1.259 & 0.540 & 3.482 & 0.604 & N.S & 0.135 \\
\hline
\end{tabular}

Data represented in Table 7 and Appendix 3 confirmed that the effect of varieties on all seed yield and its components traits was significant with the exception of the characters (pods number $/ \mathrm{m}^{2}$, pods length, and seeds weight/pod) which was found to be not significant. Maximum values of (biological yield, pod yield, average seeds number/pod and seed yield) were (5.082 ton/ha, 2.709 ton/ha, 3.554 and 2.040 ton/ha) respectively recorded by ICARDA 2706, but regarding 100 seeds weight, ICARDA 2380 gave the highest value which was $20.001 \mathrm{~g}$, while ICARDA 2380 gave minimum value of biological yield 3.997 ton/ha, and ICARDA 2561 exhibited the lowest values of (pod yield, seeds number/pod and seed yield) were (2.092 ton/ha, 2.817 and $1.584 \mathrm{ton} / \mathrm{ha})$ respectively, in which minimum weight of 100 seeds was $16.149 \mathrm{~g}$ registered by ICARDA 2706. The superiority of ICARDA 2706 in biological, seed yield and some other traits may be due to its adaptation in compare to other variety which 
was well adapted to the Sulaimani region climatic and soil conditions. This result agrees with the results of Baş et al. (2011).

Table 7. Effect of varieties on seed yield and its components of narbon vetch

\begin{tabular}{|c|c|c|c|c|c|c|c|c|}
\hline Varieties & $\begin{array}{l}\text { Biological yield } \\
\text { (ton/ha) }\end{array}$ & $\begin{array}{c}\text { Pods } \\
\text { number } / \mathbf{m}^{2}\end{array}$ & $\begin{array}{c}\text { Pod yield } \\
\text { (ton/ha) }\end{array}$ & $\begin{array}{c}\text { Pods } \\
\text { length }(\mathrm{cm})\end{array}$ & $\begin{array}{c}\text { Seeds } \\
\text { number/pod }\end{array}$ & $\begin{array}{c}\text { Seeds } \\
\text { weight/pod (g) }\end{array}$ & $\begin{array}{r}100 \text { seeds } \\
\text { weight }(\mathrm{g})\end{array}$ & $\begin{array}{c}\text { Seed yield } \\
\text { (ton/ha) }\end{array}$ \\
\hline ICARDA 2561 & 4.464 & 215.333 & 2.092 & 4.939 & 2.817 & 0.624 & 16.180 & 1.584 \\
\hline ICARDA 2380 & 3.997 & 209.167 & 2.233 & 5.311 & 3.309 & 0.726 & 20.001 & 1.656 \\
\hline ICARDA 2706 & 5.082 & 244.250 & 2.709 & 4.673 & 3.554 & 0.628 & 16.149 & 2.040 \\
\hline $\operatorname{LSD}(\mathrm{P}<0.05)$ & 0.319 & N.S & 0.271 & N.S & 0.497 & N.S & 1.127 & 0.312 \\
\hline
\end{tabular}

N.S: not significant

All traits of seed yield and its components of narbon vetch were shown in Table 8 and Appendix 2 affected significantly by different defoliation intensities. Control (not defoliated) treatment gave the highest values of these traits (biological yield, pods number $/ \mathrm{m}^{2}$, pods weight $/ \mathrm{m}^{2}$, pod length, seeds number/pod, seeds weight $/$ pod, 100 seed weight and seed yield) were (15.725 ton/ha, $735.89,8.0767$ ton/ha, $5.936 \mathrm{~cm}, 4.333$, $0.910 \mathrm{~g}, 22.196 \mathrm{~g}$ and $6.201 \mathrm{ton} / \mathrm{ha}$ ) respectively, in which the lowest values of these previous traits exhibited by severe defoliation intensity $(4 \mathrm{~cm})$ were $(0.376$ ton/ha, 20000, 0.12719 ton/ha, $5.132 \mathrm{~cm}, 2.323,0.584 \mathrm{~g}, 10.378 \mathrm{~g}$ and $0.098 \mathrm{ton} / \mathrm{ha}$ ) respectively. Previously Mitchell et al. (2010), who reported switch grass should not be harvested within below a $10-\mathrm{cm}$ stubble height to ensure carbohydrate translocation to the plant crowns for setting new tiller buds and maintaining stand productivity.

Table 8. Effect of defoliation intensities on seed yield and its components of narbon vetch

\begin{tabular}{|c|c|c|c|c|c|c|c|c|}
\hline $\begin{array}{c}\text { Defoliation } \\
\text { intensities }\end{array}$ & $\begin{array}{c}\text { Biological } \\
\text { yield (ton/ha) }\end{array}$ & $\begin{array}{c}\text { Pods } \\
\text { number } / \mathbf{m}^{2}\end{array}$ & $\begin{array}{c}\text { Pod yield } \\
\text { (ton/ha) }\end{array}$ & $\begin{array}{c}\text { Pod length } \\
\text { (cm) }\end{array}$ & $\begin{array}{c}\text { Seeds } \\
\text { number/pod }\end{array}$ & $\begin{array}{c}\text { Seeds weight } / \\
\operatorname{pod}(\mathrm{g})\end{array}$ & $\begin{array}{l}100 \text { seeds } \\
\text { weight }(\mathrm{g})\end{array}$ & $\begin{array}{c}\text { Seed yield } \\
\text { (ton/ha) }\end{array}$ \\
\hline $\begin{array}{l}\text { Control (not } \\
\text { defoliated) }\end{array}$ & 15.725 & 735.89 & 8.077 & 5.936 & 4.333 & 0.910 & 22.196 & 6.201 \\
\hline Low $(8 \mathrm{~cm})$ & 1.510 & 101.67 & 0.850 & 3.721 & 2.917 & 0.633 & 18.654 & 0.558 \\
\hline Moderate $(6 \mathrm{~cm})$ & 0.447 & 34.111 & 0.325 & 5.108 & 3.333 & 0.510 & 18.546 & 0.184 \\
\hline Severe $(4 \mathrm{~cm})$ & 0.376 & 20.000 & 0.127 & 5.132 & 2.323 & 0.584 & 10.378 & 0.098 \\
\hline $\operatorname{LSD}(\mathrm{P} \leq 0.05)$ & 0.377 & 47.321 & 0.253 & 1.344 & 0.502 & 0.201 & 1.495 & 0.398 \\
\hline
\end{tabular}

N.S: not significant

Results of Table 9 and Appendix 2 confirmed that the effect of interactions between varieties and defoliation intensities on all seed yield and its component traits of narbon vetch were significant. Maximum values of these traits (biological yield, pods number $/ \mathrm{m}^{2}$, pod yield, seeds number/pod and seed yield) were attained by the interaction between ICARDA 2706 and control (not defoliated) treatment were (17.589 ton/ha, 794.33, 9.031 ton/ha, 4.600 and 6.999) ton/ha respectively, but the interaction between ICARDA 2561 and control (not defoliated) treatment gave the highest values of (pod length and seeds weight per pod) were $(6.227 \mathrm{~cm}$ and $1.013 \mathrm{~g}$ ) respectively, but concerning 100 seeds weight, the interaction between ICARDA 2380 and control (not defoliated) treatment gave the highest weight which was $24.820 \mathrm{~g}$, while the minimum values of (biological yield and pod yield) were (0.098 and 0.046) ton/ha exhibited by interaction between ICARDA 2380 with severe defoliation intensity $(4 \mathrm{~cm})$, but when ICARDA 2561 interacted with severe $(4 \mathrm{~cm})$ defoliation intensity 
recorded the lowest values of (pods number $/ \mathrm{m}^{2}$, pod yield, seeds number/pod, 100 seeds weight, and seed yield) were (3.00, $0.008 \mathrm{ton} / \mathrm{ha}, 1.500,5.227 \mathrm{~g}$ and $0.004 \mathrm{ton} / \mathrm{ha}$ ) respectively. Regarding the average of pods length, minimum length exhibited by the interaction between ICARDA 2380 and low $(8 \mathrm{~cm})$ defoliation intensity which was $3.060 \mathrm{~cm}$, and when ICARDA 2380 interacted with moderate $(6 \mathrm{~cm})$ defoliation intensity recorded minimum value of seeds weight/pod was $0.233 \mathrm{~g}$.

Table 9. Effect of interactions between varieties and defoliation intensities on seed yield and its components of narbon vetch

\begin{tabular}{|c|c|c|c|c|c|c|c|c|c|}
\hline Varieties & $\begin{array}{c}\text { Defoliation } \\
\text { intensities }\end{array}$ & $\begin{array}{c}\text { Biological } \\
\text { yield (ton/ha) }\end{array}$ & $\begin{array}{c}\text { Pods } \\
\text { number } / \mathbf{m}^{2}\end{array}$ & $\begin{array}{c}\text { Pod yield } \\
\text { (ton/ha) }\end{array}$ & $\begin{array}{c}\text { Pods } \\
\text { length }(\mathrm{cm})\end{array}$ & $\begin{array}{c}\text { Seeds } \\
\text { number/pod }\end{array}$ & $\begin{array}{c}\text { Seeds } \\
\text { weight/pod } \\
\text { (g) }\end{array}$ & $\begin{array}{c}100 \text { seeds } \\
\text { weight } \\
\text { (g) }\end{array}$ & $\begin{array}{c}\text { Seed yield } \\
\text { (ton/ha) }\end{array}$ \\
\hline \multirow{4}{*}{ 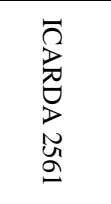 } & $\begin{array}{l}\text { Control (not } \\
\text { defoliated) }\end{array}$ & 15.046 & 694.33 & 7.194 & 6.227 & 4.467 & 1.013 & 22.177 & 5.500 \\
\hline & Low $(8 \mathrm{~cm})$ & 2.446 & 155.67 & 1.113 & 5.033 & 2.367 & 0.677 & 19.433 & 0.820 \\
\hline & Moderate $(6 \mathrm{~cm})$ & 0.184 & 8.333 & 0.053 & 3.950 & 2.933 & 0.233 & 17.883 & 0.013 \\
\hline & Severe $(4 \mathrm{~cm})$ & 0.180 & 3.000 & 0.008 & 4.547 & 1.500 & 0.572 & 5.227 & 0.004 \\
\hline \multirow{4}{*}{ 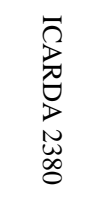 } & $\begin{array}{l}\text { Control (not } \\
\text { defoliated) }\end{array}$ & 14.539 & 719.00 & 8.005 & 6.100 & 3.933 & 0.983 & 24.820 & 6.102 \\
\hline & Low $(8 \mathrm{~cm})$ & 1.001 & 81.000 & 0.469 & 3.060 & 2.733 & 0.478 & 19.330 & 0.328 \\
\hline & Moderate $(6 \mathrm{~cm})$ & 0.350 & 29.000 & 0.410 & 5.500 & 3.533 & 0.802 & 21.590 & 0.156 \\
\hline & Severe $(4 \mathrm{~cm})$ & 0.098 & 7.667 & 0.046 & 6.583 & 3.037 & 0.641 & 14.263 & 0.036 \\
\hline \multirow{4}{*}{ 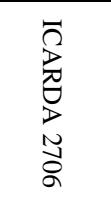 } & $\begin{array}{l}\text { Control (not } \\
\text { defoliated) }\end{array}$ & 17.589 & 794.33 & 9.031 & 5.480 & 4.600 & 0.732 & 19.590 & 6.999 \\
\hline & Low $(8 \mathrm{~cm})$ & 1.082 & 68.333 & 0.966 & 3.070 & 3.650 & 0.743 & 17.200 & 0.526 \\
\hline & Moderate $(6 \mathrm{~cm})$ & 0.807 & 65.000 & 0.512 & 5.875 & 3.533 & 0.494 & 16.163 & 0.382 \\
\hline & Severe $(4 \mathrm{~cm})$ & 0.850 & 49.333 & 0.328 & 4.267 & 2.433 & 0.540 & 11.643 & 0.253 \\
\hline \multicolumn{2}{|c|}{$\operatorname{LSD}(\mathrm{P} \leq 0.05)$} & 0.653 & 59.826 & 0.437 & 59.826 & 0.870 & 0.349 & 2.590 & 0.690 \\
\hline
\end{tabular}

N.S: not significant

\section{Conclusions}

From the results of this study, we concluded that most traits of growth, forage yield, seed yield and its components of narbon vetch were affected significantly by different varieties, defoliation intensities and their interactions as follow:

- The interaction between variety 1 and moderate defoliation intensity $(6 \mathrm{~cm})$ gave the highest values of fresh forage yield and fresh stem percent, and maximum fresh leaf percent exhibited by interaction between variety 2 and severe defoliation intensity $(4 \mathrm{~cm})$, but maximum leaves/stem ratio, showed by interaction between variety 1 and low defoliation intensity $(8 \mathrm{~cm})$.

- The interaction between variety 2 and moderate defoliation intensity $(6 \mathrm{~cm})$ awarded the highest values of plant height, no. of branches/plant, no. of leaves/plant, leaves weight/plant, leaves dry weight/plant and stem dry weight/plant, but the highest amount of stem weight/plant was offered by variety 2 when interacted with severe defoliation intensity $(4 \mathrm{~cm})$, and maximum root dry weight was obtained by interaction between variety 3 and severe defoliation intensity $(4 \mathrm{~cm})$.

- Maximum values of biological yield, pods number $/ \mathrm{m}^{2}$, pod yield, seeds number/pod, and seed yield were attained by the interaction between variety 3 and control (not defoliated) treatment, but the interaction between variety 1 and control treatment gave the highest values of pod length and seeds weight per 
pod, but concerning 100 seeds weight, the highest weight obtained by the interaction between variety 2 and control treatment.

\section{Recommendation}

We recommend from this study that there is a forage yield benefit to cutting or defoliation at shorter heights from ground level when the plants are not under stress or low in root carbohydrate levels, medium and high defoliation intensities significantly reduced available forage production. Seed production was adversely affected by defoliation intensity, and further study must be conduct at different locations and conditions to know the performance of these varieties.

\section{REFERENCES}

[1] @ griculture Online (1999): Cut it close for best performance in alfalfa. http://www.agriculture.com, April 9, 1999.

[2] Abdullah, Y., Muwalla, M. M., Qudsieh, R. I., Titi, H. H. (2010): Effect of bitter vetch (Viciaervilia) seeds as a replacement protein source of soybean meal on performance and carcass characteristics of finishing Awassi lambs. - Trop. Anim. Health Pro. 42: 293-300.

[3] Açıköz, E. (2001): Forage Crops. - Uludag Univ. Publ. no: 182, Bursa, Turkey.

[4] AL Mohamad, F., AL Younis, M. A. (2000): Agricultural Experimentation Design and Analysis. - Baghdad Univ. Ministry of Higher Education and Scientific Research, Vol. 374.

[5] Albayrak, S., Güler, M., Tongel, M. O. (2004a): Effects of seed rates on forage production and hay quality of vetch-triticale mixtures. - Asian Journal of Plant Science 3(6): 752-756.

[6] Albayrak, S., Sevimay, C. S., Tongel, M. O. (2004b): The effects of inoculation with Rhizobium on forage yield and yield components of common vetch (Vicia sativa L.). Turkish Journal of Agriculture \& Forestry 28: 405-411.

[7] Altınok, S. (2002): The effects of different mixture of hairy vetch (Viciavillosa L.) and Narbonne vetch (Vicianarbonensis L.) seeded with barley (Hordeum vulgare L.) on silage quality. - TarimBilimleriDergisi-Journal of Agricultural Sciences 8(3): 232-237.

[8] Altınok, S., Hakyemez, H. (2002): The effects on forage yields of different mixture rates of hairy vetch (ViciavillosaL.) and Narbonne vetch (Vicianarbonensis L.) seeded with barley (Hordeum vulgare L.). - TarimBilimleriDergisi - Journal of Agricultural Sciences 8(1): 45-50.

[9] Avcioğlu, R., Kavut, Y. T., Okkaoğlu, H. (2009): Narbonne Vetch (Vicianarbonensis L.). - In: Avcioglu, R. et al. (eds.) Forages-Legume Forages II. Publication of Turkish Ministry of Agricultural and Rural Affairs, Izmir, pp. 421-425.

[10] Baş, U. et al. (2011): Lathyrus sativus L. - LANDRACES 16(1): 9-14.

[11] Belesky, D. P., Fedders, J. M. (1997): Residue height influences stand dynamics of alfalfa grown on shallow soil. - Agron. J. 89: 975-980.

[12] Berger, J. D., Robertson, L. D., Cocks, P. S. (2002): Genotype $\times$ environment interaction for yield and other attributes among undomesticated Mediterranean Vicia species. Euphytica 126: 421-435.

[13] Brown, E. M., Blaser, R. E., Dunton, H. L. (1966): Leaf-Area Index and Apparent Photosynthesis under Various Microclimates for Different Pasture Species. - In: Hill, A. G. G. (ed.) Proc. 10th Int. Grassl. Congr, Helsinki, Finland. 7-16 July. Finnish Grassland Association, Helsinki, pp. 108-113. 
[14] Bryant, J. A., Hughes, S. G. (2011): Vicia. - In: Kole, C. (ed.) Wild Crop Relatives: Genomic and Breeding Resources. Legume Crops and Forages. Springer, Heidelberg, Chap. 14.

[15] Büyükburç, U., İptaş, S., (2001): The yield and yield components of some narbon vetch (Vicianarbonensis L.) lines in Tokat ecological conditions. - Turk J Agric For 25: 79-88.

[16] Firıncioğlu, H. K., Unal, S., Pank, Z., Beniwal, S. P. S. (2012): Growth and development of narbon vetch (Vicianarbonensis L.) genotypes in the semi-arid central Turkey. Spanish Journal of Agricultural Research 10(2): 430-442.

[17] Haddad, S. G. (2006): Bitter vetch grains as a substitute for soybean meal for growing lambs. - Livest. Sci. 99: 221-225.

[18] Iptaş, S., Karadağ, Y. (2009): Determination of the yield and yield components of narbon vetch (Vicianarbonensis L.) lines grown in spring. - 1st International Symposium on SustainableDevelopment, June 9-10, 2009, Sarajevo, pp. 83-88.

[19] Larbi, A., Abd El-Moneim, A. M., Nakkul, H., Jammal, B., Hassan, S., (2010): Intraspecies variations in yield and quality determinants in Vicia species: 2. Narbon vetch (Vicianarbonensis L.). - Anim. Feed Sci. Tech. 162: 20-27.

[20] Mebarkia, A., Abbas, K., Slimani, A. (2013): Vicianarbonensis L.: the importance of phosphorus fertilization and seeding rate under rainfall conditions Setif High Plains Algeria. - J. Agronomy 12(2): 93-98.

[21] Mitchell, R. B., Vogel, K. P., Schmer, M. R., Pennington, D. (2010): Switchgrass for biofuel production.

http://www.extension.org/pages/Switchgrass_for_Biofuel_Production. Accessed 30 Nov 2011.

[22] Muhammed, S. R. (2017): Response of two fenugreek Trigonellafoenum-graecum varieties to different cutting dates and nitrogen fertilizer for growth and forage yield traits under rainfed condition. - Journal of Tikrit for Agriculture Sciences 17(Special): 134142.

[23] Nizam, I., Orak, A., Kamburoglu, I., Cubuk, M. G., Moralar, E. (2011): Yield potentials of Narbonne vetch (Vicianarbonensis L.) genotypes in different environmental conditions. - Journal of Food Agriculture \& Environment 9(1): 314-318.

[24] Sadeghi, G. H., Mohammadi, L., Ibrahim, S. A., Gruber, K. J. (2009): Use of bitter vetch (Viciaervilia) as a feed ingredient for poultry. - World Poultry Sci. 65: 51-63.

[25] Sánchez-Vioque, R., Girón-Calle, J., Rodriguez-Conde, M. F., Vioque, J., De-LosMozos-Pascual, M., Santana-Méridas, O., Izquierdo-Melero, M. E., Alaiz, M. (2011): Determination of $\gamma$-glutamyl-S-ethenyl-cysteine in narbon vetch (Vicianarbonensis L.) seeds by high-performance liquid chromatography. - Anim. Feed Sci. Technol. 165(1-2): 125-130.

[26] Sheaffer, C. C., Lacefield, G. D., Marble, V. L. (1988): Cutting Schedules and Stands. In: Hanson, A. A. et al. (ed.) Alfalfa and Alfalfa Improvement. Agron. Monogr. 29. ASA, CSSA, SSSA, Madison, WI.

[27] Shen, Y., Huixin, J., Guiu, Z., Qingsheng, C. (2013): Effects of cutting height on shoot regrowth and forage yield of alfalfa (Medicago sativa L.) in a short-term cultivation system. - Japanese Society of Grassland Science, Grassland Science 59: 73-79.

[28] Tahereh, R., Arash, A., Ali, M., Karim, K., Farshid, F., Hana, S., Babak, D. (2012): Chemical composition and forage yield of three Vicia varieties (Vicia spp.) at the full blooming stage. - Italian Journal of Animal Science 11: 3.

[29] Wiersma, D. W. (2000): Alfalfa cutting height to maximize forage yield and quality. http://www.uwex.edu/ces/forage/wfc/proceedings2000/wiersma.htm. 


$$
-12490 \text { - }
$$

\section{APPENDIX}

Appendix 1. Mean squares of variance analysis for forage yield traits of narbon vetch

\begin{tabular}{|c|c|c|c|c|c|c|c|c|c|}
\hline S.O.V & d.f & $\begin{array}{l}\text { Fresh forage } \\
\text { yield (ton/ha) }\end{array}$ & $\begin{array}{c}\text { Dry forage } \\
\text { yield (ton/ha) }\end{array}$ & $\begin{array}{l}\text { Fresh } \\
\text { leaf \% }\end{array}$ & $\begin{array}{l}\text { Fresh } \\
\text { stem \% }\end{array}$ & $\begin{array}{c}\text { Dry } \\
\text { leaf \% }\end{array}$ & \begin{tabular}{|c|} 
Dry \\
stem \%
\end{tabular} & $\begin{array}{c}\text { Dry } \\
\text { matter \% }\end{array}$ & $\begin{array}{c}\text { Leaves/ } \\
\text { stem ratio }\end{array}$ \\
\hline Blocks & $\mathrm{r}-1=2$ & 0.018 & 0.011 & 0.186 & 0.573 & 0.209 & 0.196 & 0.765 & 0.065 \\
\hline A (varieties) & $\mathrm{a}-1=2$ & $7.209 *$ & $0.081 * *$ & $21.077^{*}$ & $18.598^{\text {n.s }}$ & $1.449^{\text {n.s }}$ & $0.041^{\text {n.s }}$ & $1.798^{\text {n.s }}$ & $0.156^{\text {n.s }}$ \\
\hline Error (a) & $(\mathrm{r}-1)(\mathrm{a}-1)=4$ & 0.497 & 0.004 & 2.751 & 3.097 & 0.416 & 0.074 & 0.329 & 0.040 \\
\hline $\begin{array}{c}\text { B (defoliation } \\
\text { intensities) }\end{array}$ & $b-1=2$ & $6.268 * *$ & $0.036^{\text {n.s }}$ & $36.061 * *$ & $31.484 * *$ & $0.757 *$ & $0.005^{\text {n.s }}$ & $0.735^{\text {n.s }}$ & $0.136^{*}$ \\
\hline $\mathrm{AB}$ & $(a-1)(b-1)=4$ & $1.935^{*}$ & $0.022^{\text {n.s }}$ & $17.090 * *$ & $18.525^{* *}$ & $0.302^{\text {n.s }}$ & $0.174^{\text {n.s }}$ & $0.320^{\text {n.s }}$ & $0.200 * *$ \\
\hline Error (b) & $a(b-1)(r-1)=12$ & 0.408 & 0.017 & 1.154 & 1.402 & 0.153 & 0.166 & 0.360 & 0.026 \\
\hline
\end{tabular}

N.S: Not significant; *: Significant; **: Highly significant

Appendix 2. Mean squares of variance analysis for forage yield component traits of narbon vetch

\begin{tabular}{|c|c|c|c|c|c|c|c|c|c|c|}
\hline S.O.V & d.f & $\begin{array}{l}\text { Plant } \\
\text { height } \\
(\mathbf{c m})\end{array}$ & $\begin{array}{c}\text { No. of } \\
\text { branches/ } \\
\text { plant }\end{array}$ & $\begin{array}{c}\text { No. of } \\
\text { leaves/ } \\
\text { plant }\end{array}$ & $\begin{array}{c}\text { Leaves } \\
\text { weight/ } \\
\text { plant }(g)\end{array}$ & $\begin{array}{c}\text { Dry leaves } \\
\text { weight/ } \\
\text { plant }(g)\end{array}$ & $\begin{array}{c}\text { Stem } \\
\text { weight/ } \\
\text { plant (g) }\end{array}$ & $\begin{array}{c}\text { Dry stem } \\
\text { weight// } \\
\text { plant }(g)\end{array}$ & $\begin{array}{c}\text { Root } \\
\text { weight } \\
\text { (g) }\end{array}$ & $\begin{array}{c}\text { Dry root } \\
\text { weight } \\
\text { (g) }\end{array}$ \\
\hline Blocks & $\mathrm{r}-1=2$ & 2.560 & 0.015 & 2.907 & 2.617 & 0.390 & 7.902 & 0.012 & 2.697 & 0.015 \\
\hline A (varieties) & $a-1=2$ & $225.2 * *$ & $0.017^{\mathrm{n} . \mathrm{s}}$ & $6.531^{\text {n.s }}$ & $33.802 *$ & $1.121^{\mathrm{n} . \mathrm{s}}$ & $135.8 * *$ & $0.190^{\mathrm{n} . \mathrm{s}}$ & $0.316^{\text {n.s }}$ & $0.19^{* *}$ \\
\hline Error (a) & $(\mathrm{r}-1)(\mathrm{a}-1)=4$ & 1.672 & 0.117 & 4.784 & 3.548 & 0.582 & 6.857 & 0.390 & 0.258 & 0.008 \\
\hline $\begin{array}{l}\text { B (defoliation } \\
\text { intensities) }\end{array}$ & $b-1=2$ & $6.075^{\text {n.s }}$ & $0.586^{*}$ & $50.65 * *$ & $62.293 * *$ & $1.083^{* *}$ & $29.95 * *$ & $0.371^{\mathrm{n} . \mathrm{s}}$ & $0.053^{\text {n.s }}$ & $0.002^{\text {n.s }}$ \\
\hline $\mathrm{AB}$ & $(a-1)(b-1)=4$ & $48.49^{* *}$ & $0.632 * *$ & $71.12 * *$ & $108.95 * *$ & $2.581^{* *}$ & $49.8^{* *}$ & $0.782 * *$ & $0.518^{\text {n.s }}$ & $0.03 * *$ \\
\hline Error (b) & $\mathrm{a}(\mathrm{b}-1)(\mathrm{r}-1)=12$ & 1.698 & 0.096 & 2.823 & 0.501 & 0.092 & 3.832 & 0.115 & 0.409 & 0.006 \\
\hline Total & abr-1 = 26 & & & & & & & & & \\
\hline
\end{tabular}

N.S: Not significant; *: Significant; **: Highly significant

Appendix 3. Mean squares of variance analysis for seed yield and its components of narbon vetch

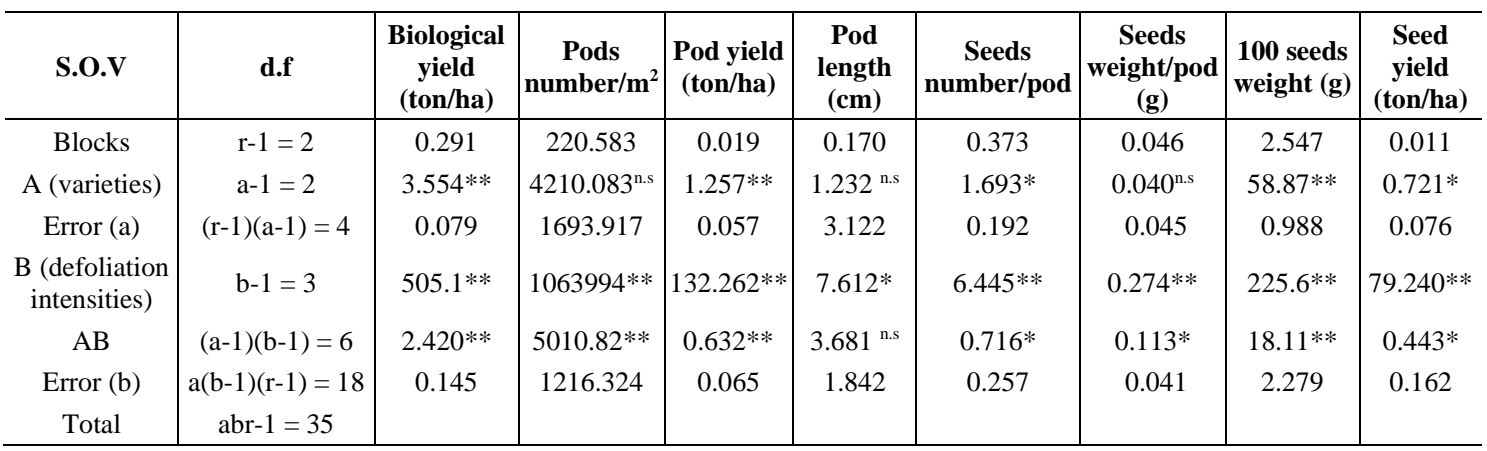

N.S: Not significant; *: Significant; **: Highly significant 